ZOOLOGIA 30 (1): 88-96, February, 2013

http://dx.doi.org/10.1590/S1984-46702013000100011

\title{
First record of Thylaeodus (Gastropoda: Vermetidae) from the Equatorial Atlantic Ocean, with the description of a new species
}

\author{
Paula Spotorno $^{1} \&$ Luiz Ricardo L. Simone ${ }^{2}$
}

\author{
${ }^{1}$ Museu Oceanográfico "Prof. Eliézer de Carvalho Rios", Universidade Federal do Rio Grande. 96200-580 Rio Grande, RS, \\ Brazil. E-mail: paula.spotorno@gmail.com \\ ${ }^{2}$ Museu de Zoologia da Universidade de São Paulo.04299-970 São Paulo, SP, Brazil. E-mail: Irsimone@usp.br
}

\begin{abstract}
The vermetid Thylaeodus equatorialis sp. nov. is endemic to the São Pedro and São Paulo Archipelago, located at the mid equatorial Atlantic Ocean. The species is closely related to Thylaeodus rugulosus (Monterosato, 1878), as indicated by similar shell characters, coloration of the soft parts, and feeding tube scars. However, T. equatorialis sp. nov. mainly differs from $T$. rugulosus in the operculum/aperture diameter ratio ( 79\% versus $100 \%)$, by having well developed pedal tentacles and fewer egg capsules in brooding females. In addition, the new species has the following unique characteristics: size almost twice as large (shell, tube aperture, erect feeding tube, protoconch and egg capsules) as the other Atlantic species; unusual method of brooding egg capsules; radula with prominent and more numerous flanking cusps; and small pustules following the suture of the protoconch. A detailed discussion on the taxonomy and biology of vermetid Thylaeodus and allies is also presented.
\end{abstract}

KEY WORDS. Mollusca; São Pedro and São Paulo Archipelago; taxonomy; anatomy Thylaeodus equatorialis sp. nov.; vermetid.

Vermetids are sessile gastropods characterized by an uncoiled shell attached to or buried in hard substrates. Their peculiar shells grow irregularly, adapting to the substratum (KeEN 1961, SAVAzZI 1996), and individuals are mobile only in the early stages after hatching (KeEn 1961). Additional data and a complete description of the family can be found elsewhere (KeEN 1961, Morton 1965, Hadfield 1970, Kelly 2007).

Brazilian reef-building vermetids are found mainly on the Northeast and Southeast coasts, between $3^{\circ} \mathrm{S}$ (northern coast of Ceará) to $22^{\circ} \mathrm{S}$ (northern coast of Rio de Janeiro) (SOARESGomes et al. 2001) including the Brazilian oceanic islands (LABOREL \& KeMPF 1965). An assembly of six vermetid gastropod species occurs along the Brazilian coast, from states of Amapá to Santa Catarina - Dendropoma irregulare (d'Orbigny, 1842); Dendropoma sp.; Petaloconchus erectus (Dall, 1888); P. myrakeenae Absalão \& Rios, 1987; P. varians (d'Orbigny, 1841), and Thylacodes decussatus (Gmelin, 1791) (Laborel \& KempF 1965, Laborel 1977, Rios \& Barcellos 1979, 1980, Barcellos et al.1989, Leal 1991, Rios 1994, Spotorno-Oliveira 2009). Nevertheless, the Brazilian vermetids are remarkably numerous, and the total number of known taxa has increased to 16 (SPOTORNo et al. 2012).

The Archipelago of São Pedro and São Paulo (also known as St. Paul's Rocks, abbreviated ASPSP) is the smallest Brazilian oceanic archipelago, located at the mid equatorial Atlantic Ocean $\left(00^{\circ} 55^{\prime} 02^{\prime \prime} \mathrm{N} 29^{\circ} 20^{\prime} 42^{\prime \prime} \mathrm{W}\right)$, about $1,010 \mathrm{~km}$ off the Brazilian coast and $1,824 \mathrm{~km}$ off the African coast. The marine flora and fauna of ASPSP are of considerable biogeographic interest because of their isolation, ASPSP's intermediate loca- tion between the Brazilian and West African faunal provinces and the archiplepelago's small area (EDWARDs \& LUBвоck 1983b). The archipelago has been visited by scientific expeditions since 1799 (EDWARDs 1985) and some publications on the marine biology and ecology of ASPSP have been published. Literature data indicates that Dendropoma sp. is the only vermetid record in the species checklist (Edwards \& Lubbock 1983a, Edwards 1984).

The present contribution is part of a research program initiated several years ago, and which investigates the ASPSP marine molluscan fauna (SРотоRNo-Oliveira et al. 2003). So far, a total of 48 mollusk taxa have been recorded from tide pools and rocky shores in the Belmonte Islet, ASPSP (SPOTORNO-OliveIRA et al. 2009), and five recently described species (SIMONE 2008, $2009 a, b)$, two of which are considered endemic (SIMONE 2008, 2009a).

The ASPSP vermetids are distributed along the intertidal shoreline and down in tide pools, which are often flushed with seawater when the tide is high (EDwards \& LubBock 1983a,b, EDWARDS 1984). Two vermetid taxa have been recorded from this locality (SPOTORNo-Oliveira et al. 2009), one of which is herein described as new.

The genus Thylaeodus Mörch, 1860, type species Bivona contorta Carpenter, 1857 (SD by KeEN 1961: 191), from Tropical West America, is characterized by shells of moderate to small diameter, feeding tube scars present in most specimens, operculum slightly overlapping foot (though not reaching the diameter of the aperture, with less than $3 / 4$ the diameter of the 
aperture), operculum with a central spiral lamina in the upper surface of 1.5 whorls, and inner shell surface lacking longitudinal columellar lamellae (KeEn 1961, 1971, MorTon 1965). Thylaeodus was believed to be absent from the mid equatorial Atlantic Ocean and the species described herein is the first record of the genus for that region.

\section{MATERIAL AND METHODS}

Samples were removed from the rock using hammer and chisel. Specimens were fixed and preserved in 80 to 100\% ethanol and deposited in MORG and MZSP malacological collections. Soft parts were removed after crushing the shell with a small lathe. Anatomy, shells, radula, protoconch and opercula were studied and photographed with a Canon Power Shot S45 camera connected to a binocular stereomicroscope Leica MZ125. The dissections were performed by standard techniques, with specimens immersed in fixative under a stereo-microscope. For detailed examination, some shells, protoconchs and radulae samples were mounted on stubs, coated with a gold-palladium alloy and observed under scanning electron microscope in the Laboratório de Microscopia Eletrônica of the Museu de Zoologia, Universidade de São Paulo (MZSP).

Institutional abbreviations are as follows: (MORG) Museu Oceanográfico "Prof. Eliézer de Carvalho Rios", Universidade Federal do Rio Grande, Brazil; (MZSP) Museu de Zoologia da Universidade de São Paulo, Brazil; (MNRJ) Museu Nacional, Universidade Federal do Rio de Janeiro, Rio de Janeiro, Brazil; (USNM) National Museum of Natural History, Smithsonian Institution, Washington, D.C., United States.

\section{TAXONOMY}

\section{Thylaeodus equatorialis sp. nov.}

Figs 1-18

Vermetidae sp.: Spotorno-Oliveira et al., 2009: 180.

Thylaeodus sp.: Spotorno et al., 2012: 06.

Type locality. Brazil, Pernambuco: São Pedro e São Paulo Archipelago (Belmonte Inlet, Enseada, 00 $55^{\prime} 01^{\prime \prime} \mathrm{N}-29^{\circ} 20^{\prime} 44^{\prime \prime} \mathrm{W}$, 3-10 m), , 7.xi.2007, Simone \& Cunha leg.

Type material. Holotype MORG 51621. Paratypes from the type locality: MORG 50785, 10 spm, vii.2005; MORG 51296, 1 spm, iii.2005, both Spotorno leg.; MORG 51622, 3 spm, 07.xi.2007; MZSP 82314, 5 spm, iii.2005; MZSP 86531, 3 spm, 28.x.2007; MZSP 87469, 3 spm, 27.x.2007; MZSP 86676, 2 spm, 09.xi.2007; MZSP 86627, 32 spm, 07.xi.2007; MZSP 86628, 32 spm, 07.xi.2007; MZSP 86566, 85 spm, 07.xi.2007; MNRJ 30504, 2 shells, 07.xi.2007; USNM, 2 shells, 07.xi.2007, all Simone \& Cunha leg.

Diagnosis. Shallow-water species found in ASPSP, of $\sim 9$ $\mathrm{mm}$ long, $\sim 1.7 \mathrm{~mm}$ diameter. Protoconch with small pustules following suture. Soft body coloration overall milky-white, with some red bands in head-foot. Operculum with $~ 79 \%$ of aperture diameter. Radula with strong prominent flanking cusps; lateral tooth with 7-9 flanking cusps on outside; outer marginal tooth (second marginal) with 7-10 flanking cusps on inner side. Mantle border of brooding females with deep incision along midline. Brooding egg capsules both freely in interior of mantle cavity and attached to inner shell surface by stalks; up to three egg capsules, containing 2-6 embryos. Males with mantle border thickened.

Description. Holotype: part of cluster of specimens; consisting of isolated tube. Aperture diameter: $1.5 \mathrm{~mm}$; length 6 mm. Shell. Protoconch (Fig. 1): barrel-shaped, slender and stretched, buried by teleoconch whorls; with 2.5 whorls. Protoconch average length: $1.43 \pm 0.05 \mathrm{~mm}$ (range 1.3 to 1.6 $\mathrm{mm}, \mathrm{n}=7$ ); width: $0.77 \pm 0.04 \mathrm{~mm}$ (range 0.7 to $0.9 \mathrm{~mm}, \mathrm{n}=7$ ). At attachment, protoconch positioned on side with outer apertural edge against substrate. Pre-attachment protoconch with slightly wavy surface, subsequent protoconch whorls smoothsurfaced, translucent, color light amber with dark brown at suture; small pustules following suture after first half-whorl. Teleoconch (Figs 2-6 and 18): 3 to 5 loops of tubular teleoconch coiled in variable shapes; length averages $9.06 \pm 0.55 \mathrm{~mm}$ (range from 7 to $11 \mathrm{~mm}, \mathrm{n}=7$ ). Early whorls piled up attached to substrate, arranged into irregular stack or expanding laterally, rarely forming open loops; last whorl becoming emergent above substrate. First whorls thicker, color pink or translucent-brown, becoming paler or translucent-white next to aperture. Emergent tube (or feeding tube) with average of $7.42 \pm 1.90 \mathrm{~mm}$ (from 3 to $13 \mathrm{~mm}, \mathrm{n}=5$ ), forming erect tube above substrate, thin walled, white-light or pink in color, section rounded, narrower and more finely ridged than first whorls of teleoconch. Aperture circular with average diameter of $1.71 \pm 0.14 \mathrm{~mm}$ (range from 1.1 to 2.2 $\mathrm{mm}, \mathrm{n}=7$ ). Early post larval sculpture of axial ribs, subsequent sculpture of axial growth lines, without longitudinal (spiral) sculpture. Most specimens with remnants of earlier feeding tubes, i.e, feeding tube scars (Figs 2, 4, and 6: fc). Inner shell surface smooth, color usually light brown, sometimes paler. Longitudinal columellar lamellae lacking. Head-foot (Figs 7 and 10): Head not especially broad, bulbous, about a half of foot length. Snout large and cylindrical, with mouth as vertical slit in ventral-terminal surface. Cephalic tentacles elongated, emerging laterally from snout base, weakly longer than snout. Eyes small, black, immersed in ventral region of tentacles' base. Color overall milkywhite, with some red pigmented band in some specimens. Foot occupying $\sim 1 / 2$ of total head-foot volume. Dorsal region containing pair of well developed pedal tentacles, longer than foot, and dorsoventrally flat propodial pad. Sole oval. Ventral foot surface with transverse folds, scarce light pigment spots in milkywhite specimens, more evident near operculum. Columellar muscle well developed and robust, thick anteriorly, occupying $\sim 70-80 \%$ of total body length. Operculum (Figs 8 and 9): Flat, circular, corneous, thin; transparent to translucent light yellow; 


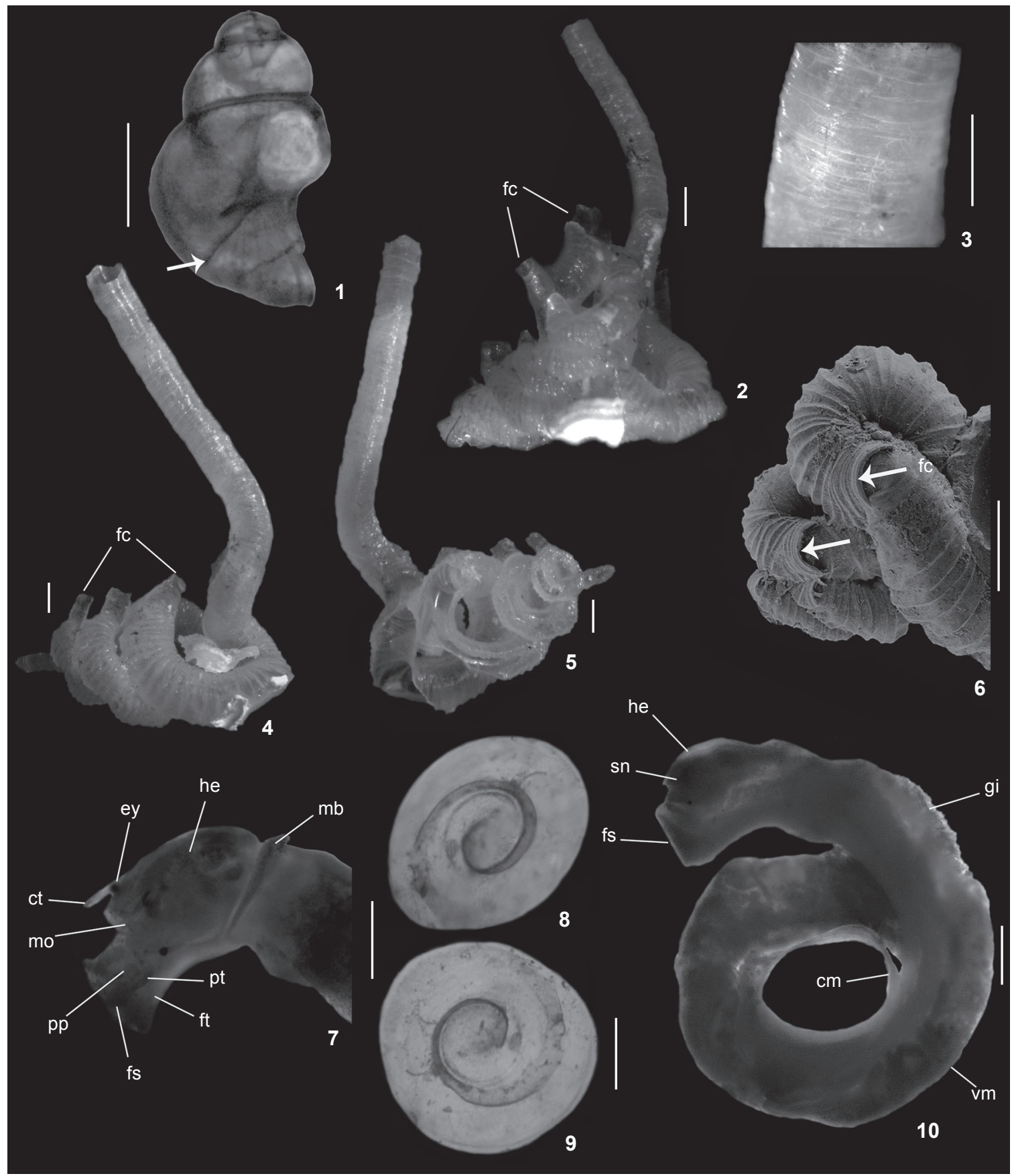

Figures 1-10. Thylaeodus equatorialis sp. nov.: (1) paratype MORG 50785 protoconch, arrow pointing early teleoconch whorl; (2) paratype MZSP 86566 entire shell, piled up whorls, with remnants of earlier feeding tubes (feeding tube scars); (3) paratype MORG 50785 detail of sculpture of the emergent tube; (4) holotype, surface sculpture of the teleoconch with feeding tube scars; (5) Same, ventral view of whorls; (6) Paratype MORG 50785, SEM, detail of early regions, arrow pointing remnants of earlier feeding tubes (fc); (7) same, headfoot, detail of anterior region, lateral-left view; (8-9) same, opercula of two specimens, external view; (10) same, female extracted from the shell, lateral-left view. (cm) Columellar muscle, (ct) cephalic tentacles, (ey) eye, (fc) feeding tube scars, (fs) foot sole (metapodium), (ft) foot, (gi) gill, (he) head, (mb) mantle border, (mo) mouth, (pp) propodial pad, (pt) pedal tentacles, (sn) snout, (vm) visceral mass. Scale bars: $1,3,7,8,9=0.5 \mathrm{~mm} ; 4-5=1.5 \mathrm{~mm} ; 2,6,10=1 \mathrm{~mm}$. 
paucispiral, with slightly raised spiral lamella of 2.5 whorls, and small mammillar projection on pedal surface. Average diameter: $1.36 \pm 0.05 \mathrm{~mm}$ (from 1.2 to $1.5 \mathrm{~mm}, \mathrm{n}=5$ ), about $73 \%$ of aperture diameter. Operculum covering entire dorsal surface of foot. Mantle organs (Fig. 10): Mantle border thin, color yellowish-white. Pallial cavity about $1 / 3$ of soft parts length. Osphradium elongated, ridge-like, $\sim 30 \%$ of gill length. Gill extending about total length of mantle cavity; filaments shorter than pallial cavity height; triangular, somewhat taller than wide. Visceral mass (Fig. 10): yellowish-white in color. Adult average length: $18.1 \pm 0.87 \mathrm{~mm}$ (from 15 to $20 \mathrm{~mm}, \mathrm{n}=5$ ). Visceral mass occupying about $2 / 3$ of total length, filling all available shell space up to posterior end. Posterior lobe of digestive gland long, occupying most of visceral mass, pale green to light brown, with minute superficial black spots. Posterior end forming slender tail, comprising gonadal tissue. Gonad along ventral surface of visceral mass, compressing digestive gland and of about same length. Radula (Figs 11 and 12, Table I): Rachidian tooth trapezoidal, main cusp strong and four to five flanking cusps on either side. Inner margin of lateral tooth fitting into deep marginal depressions of rachidian tooth; cusp arrangement on triangular cutting edge as in central tooth. Lateral tooth wider than high, main cusp strong, seven to nine flanking cusps on outside, three on inside. Marginal teeth similar to lateral, hooklike, long, slender, with long and strong main cusp. Inner marginal tooth with three to four inner and five to seven outer flanking cusps. Outer marginal tooth smooth, without cusp outside, and seven to ten flanking inner cusps (Fig. 11, arrow). Brood protection and early ontogeny (Figs 13-17): Anterior roof of mantle cavity splitting out along midline in brooding females, accommodating attachment of transparent ovoid egg capsules to interior of shell. Right side lying rectum and left side of gill filaments. Two brooding styles observed simultaneously: freely inside mantle cavity and attached egg capsules by stalks in inner shell surface. Females developing egg capsules in different stages, from nurse eggs to developing veligers and late stage of juveniles; egg capsules brood embryos in different simultaneous stages, being all embryos within a single capsule at same stage of development. Maximum of three capsules, with average dimensions of $2.76 \mathrm{~mm} \pm 0.19 \mathrm{~mm}$ (range 2 to $3 \mathrm{~mm}, \mathrm{n}=5$ ) in length and $1.70 \mathrm{~mm} \pm 0.16 \mathrm{~mm}$ (range 1.1 to $2 \mathrm{~mm}, \mathrm{n}=5$ ) in width; 2 egg capsules lying free in mantle cavity and one stalked; stalked egg capsule, elongated, containing apparently polar bodies (nurse eggs) and developed veligers; capsules lying free in pallial cavity, without stalks, spherical or elongated; containing about $4 \pm 0,82$ embryos (range 2 to $6, n=4$ ). Juvenile shells with post-metamorphosis averages $1.14 \pm 0.17 \mathrm{~mm}$ (range from 0.9 to $2.3 \mathrm{~mm}, \mathrm{n}=8$ ) in length and $0.65 \pm 0.03$ (range from 0.6 to $0.8 \mathrm{~mm}, \mathrm{n}=8$ ) in width; barrel-shaped, ornamentation smooth and translucent, about $21 / 3$ whorls, deeply marked brown suture with small pustules following suture. Soft parts unpigmented and translucent with two black eyes like dark spots through shells. In males, mantle border thickened and entirely lacking longitudinal flaps on dorsal region.

Distribution. Only know from the type locality.

Habitat. Sessile, attached to rocks from intertidal to infratidal level $(10 \mathrm{~m})$. Clustering under-surfaces of rocks from rocky pools covered by pink sponge Darwinella rosacea Hechtel, 1965 (Fig. 17).

Etymology. The specific epithet refers to the equatorial geographic position, from mid-Atlantic Ocean, close to Equator line, where this species was found.

\section{DISCUSSION}

Thylaeodus equatorialis sp. nov. is similar to T. rugulosus (Monterosato, 1878), from Azores and Mediterranean, sharing shell characters such as overall coloration of the soft parts, yellowish-white, and the remnants of earlier feeding tubes present in most specimens (Table II). However, the most noticeable difference between T. equatorialis sp. nov. and T. rugulosus is in their sizes. The dimensions of the shells, the aperture diameter, the erect feeding tube, the protoconch and the operculum, are almost twice as large as in T. equatorialis sp. nov. Moreover, there are some differences in the radula and operculum/aperture diameter ratio. The operculum in T. equatorialis sp. nov. is not as wide ( $\sim 79 \%$ of aperture's size) as in T. rugulosus. In the latter, the operculum fills the aperture. A comparison between the radulae is presented below. Furthermore, T. equatorialis sp. nov. has well developed pedal tentacles, which are absent in T. rugulosus; and the female produces fewer numbers of brooded egg capsules (three capsules) when compared with females of T. rugulosus (with

Table I. Radular data among the species of Thylaeodus reviewed.

\begin{tabular}{|c|c|c|c|c|c|c|c|c|}
\hline \multirow{3}{*}{ Species } & \multicolumn{7}{|c|}{ Flanking cusps } & \multirow{3}{*}{ Reference } \\
\hline & \multirow[t]{2}{*}{ Central tooth } & \multicolumn{2}{|c|}{ Lateral tooth } & \multicolumn{2}{|c|}{ Inner marginal tooth } & \multicolumn{2}{|c|}{ Outer marginal tooth } & \\
\hline & & Inner & Outer & Inner & Outer & Inner & Outer & \\
\hline Thylaeodus equatorialis sp. nov. & $4-5$ & 3 & $7-9$ & $3-4$ & $5-7$ & $7-10$ & 0 & Present study \\
\hline Thylaeodus rugulosus & $4-5$ & - & $4^{*}$ & $4-5$ & $4-5$ & $5-6$ & 0 & BieLER (1995) \\
\hline Thylaeodus granulatus & 2 & 2 & 4 & 1 & $1-2$ & - & - & SCHIAPARELLI (1995) \\
\hline Thylaeodus contortus & $3^{*}$ & $2^{*}$ & $3^{*}$ & $1^{*}$ & $5^{*}$ & $4^{*}$ & $0^{*}$ & MORTON (1965) \\
\hline
\end{tabular}

* Available data from sketch/figures, - Data unavailable. 


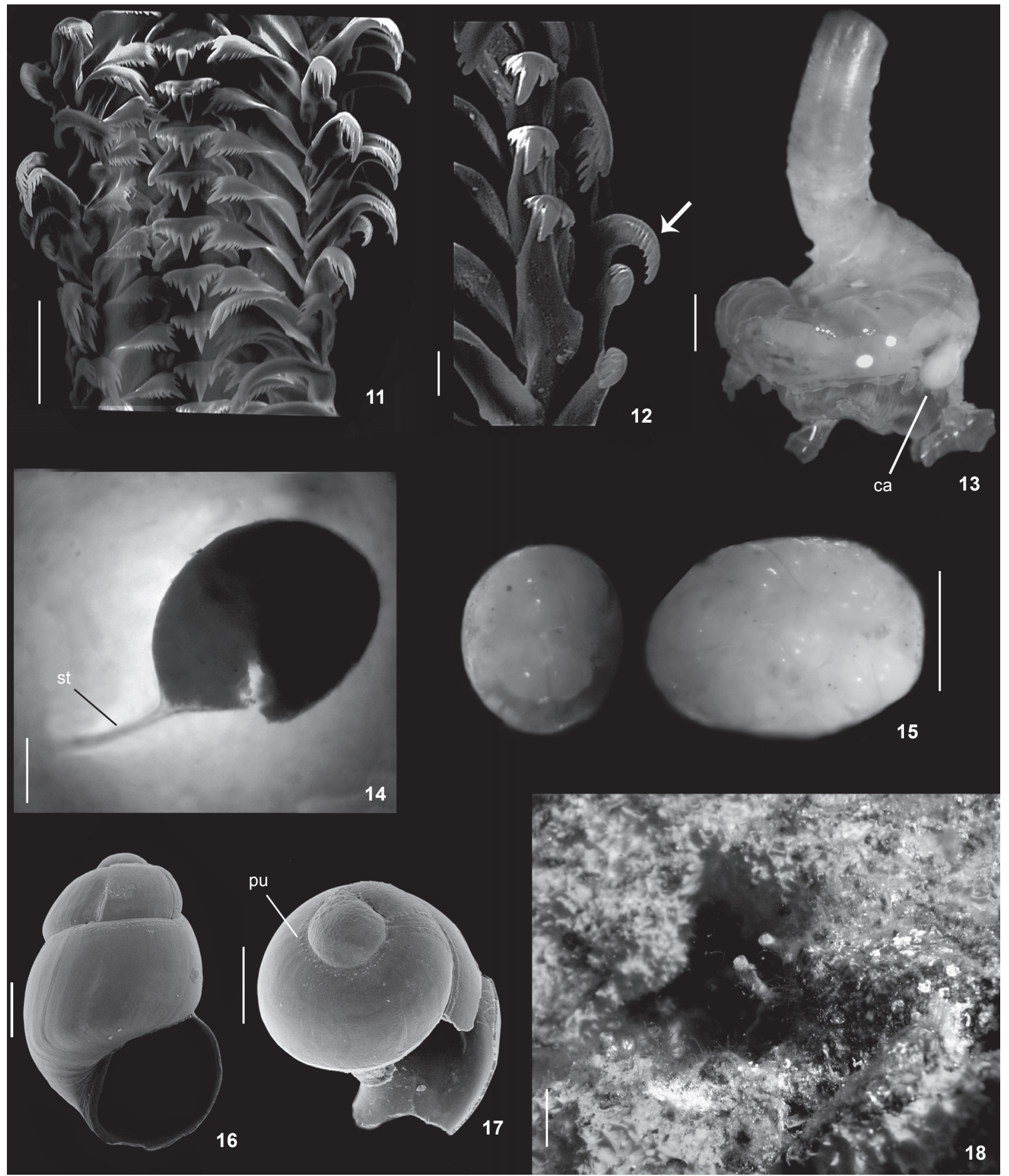

Figures 11-18. Thylaeodus equatorialis sp. nov., paratypes MORG 50785: (11) radula, SEM; (12) same, arrow pointing inner flanking cusps in marginal tooth; (13) shell with part of whorl removed to expose de egg capsule (ca); (14) stalked egg capsule; (15) two ovoid egg capsules; (16) shell of intracapsular juvenile, SEM, after metamorphosis; (17) shell of intracapsular juvenile, SEM, apical aspect, with small pustules following the suture; (18) a cluster of specimens embedded in pink sponge Darwinella rosacea. (ca) Egg capsule, (pu) pustules (st) stalk of egg capsule. Scale bars: $11,14,15=0.5 \mathrm{~mm} ; 12=0.1 \mathrm{~mm} ; 13=2.0 \mathrm{~mm} ; 16,17=1.0 \mathrm{~mm} ; 18=6.0 \mathrm{~mm}$. 
4-8 capsules). Meanwhile, T. equatorialis produces two types of brood egg capsules: stalked, and free inside the mantle cavity, with a maximum of three capsules, with $2.6 \times 1.70 \mathrm{~mm}$ in average diameter containing 2-6 developing embryos; T. rugulosus broods 4-8, always stalked egg capsules, with dimensions about $0.75 \times 0.95$ to $0.80 \times 1.2 \mathrm{~mm}$, containing 3-5 developing embryos (BIELER 1995) (Table II).

Thylaeodus equatorialis sp. nov. also shares some features with an unidentified vermetid from Hawaii, Florida and Guam (KeLLY 2007), provisionally named "Hadfield's vermetid" (STRATHMANN \& STRATHMAnN 2006), still waiting for a taxonomic revision. The shared features are related to teleoconch coloration, sculpture and operculum/aperture diameter ratio. However, both species differ sharply in size. The shell dimensions, tube aperture, erect feeding tube, operculum and juvenile protoconch of T. equatorialis sp. nov. are almost twice as large as in the Hadfield's vermetid (Thylaeodus sp., Table II). The headfoot color pattern of $T$. equatorialis ranges from yellowish to white, unlike the rose to dark brown coloration of the Hadfield's vermetid. Both species also show differences in the brood protection: up to three egg capsules with up to six embryos are brooded in the mantle cavity of $T$. equatorialis, whereas the Hadfield's vermetid broods 13 stalked egg capsules with 130 to 200 embryos. Another remarkable feature refers to the intracapsular development is the occurrence of a rare form of intracapsular adelphophagy (sibling cannibalism). It was not observed in this study, neither in T. rugulosus (BIELER 1995), but only in the Hadfield's vermetid (STRATHMANN \& Strathmann 2006).

Even though T. equatorialis sp. nov. is similar to the IndoPacific Thylaeodus enderi Schiaparelli, 2000 in the general morphology of the soft parts and in its association with sponges (Schiaparelli \& Metivier 2000), it is easily distinguished from it in having a smaller aperture diameter, a larger barrel-shaped protoconch, the head with two well developed cephalic tentacles, and females with the mantle division brooding larger egg capsules and fewer embryos (Table II).

The new species is easily distinguished from Thylaeodus granulatus (Gravenhorst, 1831), from the Mediterranean Sea, mainly in shell sculpture and the ratio operculum/aperture diameter. While the operculum of T. equatorialis sp. nov. occupies almost $2 / 3$ of the diameter of the aperture, it fills $1 / 3$ to $1 /$ 4 of it in T. granulatus (Scuderi 1999) or even up to $1 / 8$ (SChiaparelli 1995) (Table II).

Thylaeodus equatorialis sp. nov. also shows affinities with Thylaeodus contortus (Carpenter, 1857) from southern California in the anatomical organization and general shape. However, it differs mainly in having longitudinal sculpture, a larger dimension of the shell, smaller pedal tentacles and operculum/ aperture diameter ratio of $\sim 79 \%$, instead of 50\% (KeEN 1961, 1971, Morton 1965) (Table II).

The literature information on the number of radular flanking cusps of Thylaeodus species is quite vague, as summarized in Table I. The radula of T. equatorialis is similar to that described for other vermetids (MoRTon 1965, Bandel 1984, Bieler 1995, Schiaparelli 1995). The flanking cusps of the central tooth have the same pattern (4-5) in T. equatorialis and T. rugulosus (BIEler 1995), but differ in the number on other teeth.

Thylaeodus equatorialis has a different radula, with strong prominent flanking cusps in comparison with other species of the genus, differing considerably from them by the great number of flanking cusps of the lateral tooth (7-9 outer flanking cusps) and the second marginal tooth (7-10 inner flanking cusps), in comparison with the available radula data (Table I). From a taxonomic point of view, the radula, added to other morphological features, supposedly provide characters for a better specific classification, even in closely related species (Morton 1951, Schiaparelli 1995), as demonstrated for all Hawaiians vermetids (MorTon 1965, HADFIELD et al. 1972).

Another remarkable feature of the shell of T. equatorialis is the small pustules following the suture of the protoconch, as well as the barrel-shape of the shell. They are unusual characters for this genus and are unique for a Thylaeodus species. On the other hand, these granulated protoconchs are common in species of Petaloconchus (P. Spotorno, pers. obs.).

The reproductive anatomy of $T$. equatorialis has some unusual features, particularly the presence of a flap dividing the mantle in females, and the two ways of brooding egg capsules. Females of T. equatorialis sp. nov. can brood their egg capsules simultaneously attached to the internal side of the shell, suspending them in the mantle cavity through a septum in the mantle, and also freely inside the mantle cavity. Each capsule contains the same stage of embryo development; however, the stages of development vary between capsules, evidencing a continuous reproduction (Hadfield 1989, Miloslavich \& Penchaszadeh 1992, Phillips \& Shima 2009). By contrast, both Hadfield's vermetid and T. rugulosus broods stalked egg capsules only (Bieler 1995, Strathmann \& Strathmann 2006), and T. enderi broods free egg capsules inside the mantle cavity (SChiaparelli \& MÉtivier 2000).

The brooding of stalked egg capsules seems to be the rule in Thylacodes (Morton 1951, Hadfield et al. 1972, Hughes 1978a,b, SCheuWimmer \& Nishiwaki 1982, Kelly 2007), Petaloconchus (Hadfield 1970, 1989, Hadfield et al. 1972, Hughes 1978b, Bandel 1984, Strong 2003, Kelly 2007), Vermetus (Morton, 1965, Miloslavich \& Pechazadeh 1992, Bieler 1995, Calvo \& Templado 2004) and Thylaeodus (Bieler 1995, Strathmann \& Strathmann 2006); whereas in Dendropoma spp., they are more often free inside the mantle cavity (Morton 1965, Hadfield et al. 1972, Hughes 1978a, Calvo et al. 1998, Pacheco \& Laudien 2008). However, there are some exceptions, as presented here, and also observed by HADFIELD et al. (1972), Hughes \& Lewis (1974), and Schiaparelli \& Metivier (2000).

According to Hadfield et al. (1972) and Hughes (1978a), the type of brooding must be considered as a tendency rather than a phylogenetic constraint. Nevertheless, we emphasize that both types of brooding had never been recorded simultaneously in a Vermetidae species. 


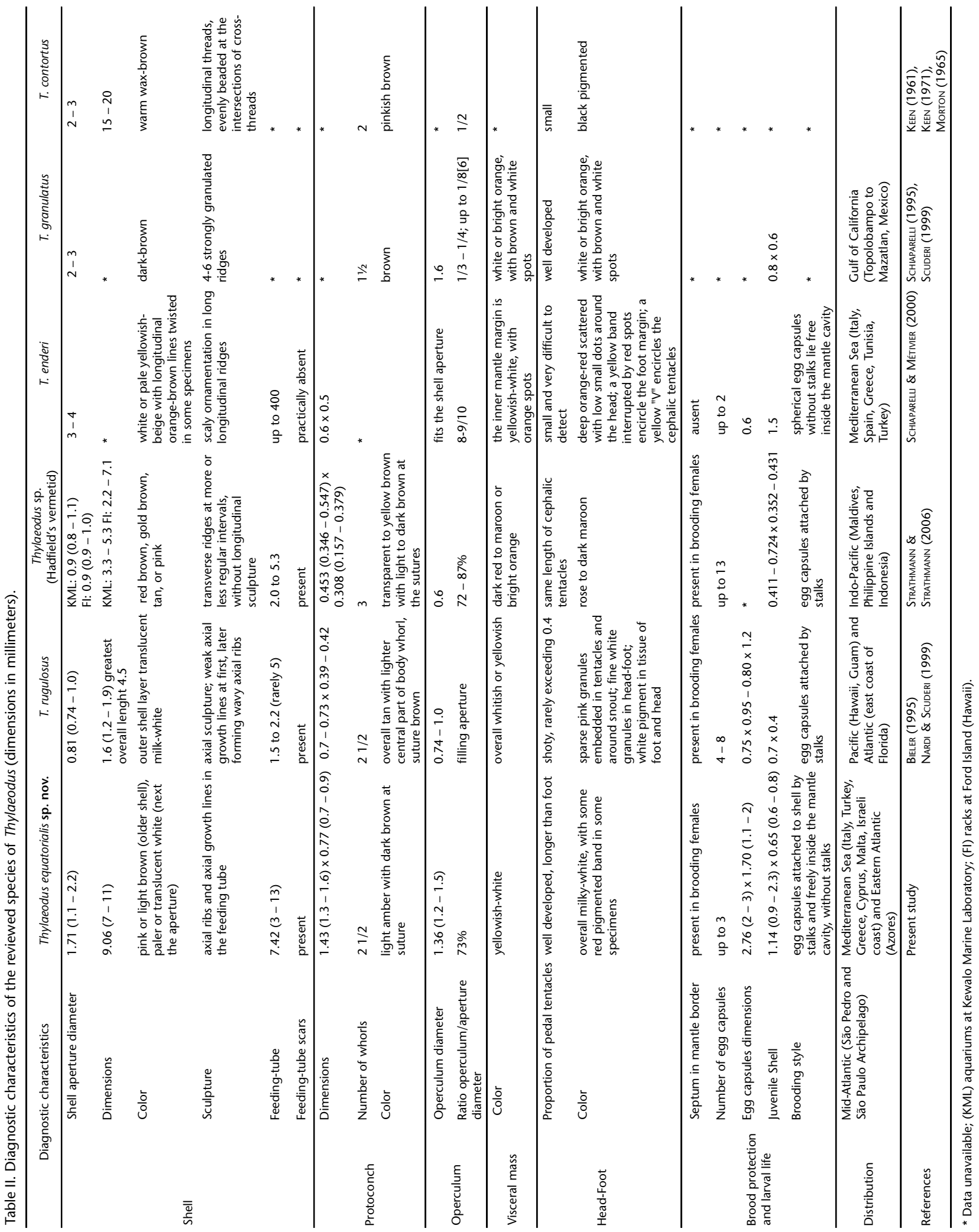

ZOOLOGIA 30 (1): 88-96, February, 2013 
Some vermetid species, like T. equatorialis sp. nov., can produce temporary calcareous tubes, called feeding tubes. Once lost, they leave characteristic scars along the shell (KeEN 1961). These scars have been erroneously considered as distinctive taxonomic characters, as discussed by Bieler (1995). Feeding tube scars are expressed only in some situations due to the plasticity of the vermetids in modify the shell structure after environmental changes, or following shell damages (SCHIAPARELLI 1995, Schiaparelli \& Cattaneo-Vietti 1999). The new species is found in habitats which are generally flushed with seawater, for instance rock pools. It is possible that high hydrodynamic forces in the area cause erosion in these shells producing the feeding tubes as suggested by Keen (1961), SAvazzi (1996) and Schiaparelli \& Cattaneo-Vietti (1999).

The close similarity between Vermetus and Thylaeodus is noteworthy. A sharp distinction between both genera is problematic, and it is not within the scope of the present study. Certainly, further investigations are needed in order to distinguish or to synonymize these taxa. Additionally, it is important to emphasize that the present study broadens the distribution of Thylaeodus to the mid Equatorial Atlantic.

\section{ACKNOWLEDGEMENTS}

A special thank to the Brazilian Navy for providing the infrastructure for the expedition. We are grateful to the following persons: Rüdiger Bieler and Richard Strathmann for the suggestions on earlier versions of this manuscript; the researchers that helped with specimens' collecting, Carlo M. Cunha, Eric P. Gonçalves (MZSP); Paulo H. Mattos, Claudio R. Trindade, Bruna V. Brites and Leonardo M. Furlanetto (FURG); Fernando Moraes (MNRJ) for helping with the identification of the sponge. This study was supported by governmental grants from the Conselho Nacional de Desenvolvimento Científico e Tecnológico (CNPq, processes 558436/2005-6 and 48.0036/ 2004-7), and a scholarship granted to the senior author.

\section{LITERATURE CITED}

BANDEL, K. 1984. The radulae of Caribbean and other Mesogastropoda and Neogastropoda. Zoologische Verhandelingen 214: 1-188.

Barcellos, L.; E.C. Rios \& R.S. AbsalÃo. 1989. Micromoluscos do substrato inconsolidado do Atol das Rocas, RN, Brasil: A diversidade como fator de inferência ambiental. Revista Brasileira de Biologia 49 (2): 545-552.

Bieler, R. 1995. Vermetid gastropods from Sao Miguel, Azores: Comparative anatomy, systematic position and biogeographic affiliation. Açoreana (Suppl.): 173-192.

Calvo, M. \& J. Templado. 2004. Reproduction and development in a vermetid gastropod, Vermetus triquetrus. Invertebrate Biology 123: 289-303.

Calvo, M.; J. Templado \& P.E. Penchaszadeh. 1998. Reproductive biology of the gregarious mediterranean gastropod Dendropoma petraeum. Journal of the Marine Biological Association of the United Kingdom 78: 525-549.

EDWARDS, A.J. 1984. Marine biology of Saint Paul's Rocks, equatorial Atlantic Ocean, In: Divers, submersibles and marine science. Occasional Papers in Biology, Memorial University of Newfoundland 9: 58-75.

EDWARDS, A.J. 1985. Saint Paul's Rocks: a bibliographical review of the natural history of a Mid-Atlantic island. Archives of Natural History 12 (1): 31-49.

Edwards, A.J. \& R. Lubbock. 1983a. The ecology of Saint Paul's Rocks (Equatorial Atlantic). Journal of Zoology London 200: 51-69.

Edwards, A.J. \& R. Lubbock. 1983b. Marine zoogeography of St. Paul's Rocks. Journal of Biogeography 10: 65-72.

Hadfield, M. G. 1970. Observations on the anatomy and biology of two California vermetid gastropods. The Veliger 12: 301309.

Hadfield, M.G. 1989. Latitudinal effects on juvenile size and fecundity in Petaloconchus (Gastropoda). Bulletin of Marine Science 45: 369-376.

Hadfield, M.G.; E.A. Kay; M.U. Gillette \& M.C. Loyd. 1972. The Vermetidae (Mollusca: Gastropoda) of the Hawaiian Islands. Marine Biology 12: 81-98.

Hughes, R.N. 1978a. The biology of Dendropoma corralinaceum and Serpulorbis natalensis, two South African vermetid gastropods. Zoological Journal of the Linnean Society 64: 111-127.

Hughes, R.N. 1978b. A new species of Serpulorbis (Gastropoda, Vermetidae) from South Africa. The Veliger 20 (3): 288-292.

Hughes, R.N. \& A.H. Lewis. 1974. On the spatial distribution, feeding and reproduction of the vermetid gastropod Dendropoma maximum. Journal of Zoology 172: 531-547.

Kelly, W.C. III. 2007. Three new vermetid gastropod species from Guam. Micronesica 39 (2): 117-140.

KeEN, A.M. 1961. A proposed reclassification of the gastropod family Vermetidae. Bulletin of the British Museum (Natural History) (Zoology) 7: 183-213.

Keen M. 1971. Sea Shells of Tropical West America; Marine Mollusks from Baja California to Peru. Stanford, Stanford University Press, 1064p.

LABOREL, J. 1977. Are reef-building vermetids disappearing in the South Atlantic? In: III International Coral Reef Symposium, Miami, p. 233-237.

Laborel, J. \& M. Kempr. 1965. Formações de vermetos e algas calcárias nas costas do Brasil. Trabalhos do Instituto Oceanográfico da Universidade Federal de PE 7/8: 33-50.

LEAL, J.H. 1991. Marine Prosobranch Gastropods from Oceanic Islands off Brazil: Species composition and Biogeography. Oegstgeest, Universal Book Services, W. Backhuys, 418p.

Miloslavich, P.A. \& P.E. Penchaszadeh. 1992. Reproductive biology of Vermetus sp. and Dendropoma corrodens (Orbigny, 1842): two vermetid gastropods from the Southern Caribbean. The Veliger 35 (1): 78-88. 
Morton, J.E. 1951. The structure and adaptations of the New Zealand Vermetidae. Part 1. The genus Serpulorbis. Transactions and Proceedings of the Royal Society 79: 1-19.

Morton, J.E. 1965. Form and function in the evolution of the Vermetidae. Bulletin of the British Museum (Natural History) 11 (9): 583-630.

NARdi, G. \& D. Scuderi. 1999. Systematic arrangement and geographic distribution of Vermetus (V.) rugulosus (Monterosato, 1878). La Conchiglia 31 (293): 47-49.

Pacheco, A. \& J. Laudien. 2008. Dendropoma mejillonensis sp. nov., a new species of vermetid (Caenogastropoda) from Northern Chile. The Veliger 50 (3): 219-224.

Phillips, N. \& J. Shima. 2009. Reproduction of the vermetid gastropod Dendropoma maximum (Sowerby, 1825) in Moorea, French Polynesia. Journal of Molluscan Studies 76: 133-137.

Rios, E. C. 1994. Seashells of Brazil. Rio Grande, Museu Oceanográfico, Fundação Universidade do Rio Grande, 330p.

Rios, E.C. \& L. BARCellos. 1979. Nuevas ocurrencias de moluscos marinos para el Archipiélago de Fernando Noronha. Comunicaciones de la Sociedad de Malacología de Uruguay 5 (37): 163-166.

Rios, E.C. \& L. BARCellos. 1980. Nuevos hallazgos de moluscos marinos para el Archipelago de Abrolhos, Bahia. Comunicaciones de la Sociedad de Malacología de Uruguay 5 (39): 305-310.

SAvazzi, E. 1996. Adaptations of vermetid and siliquariid gastropods. Palaeontology 39 (1): 157-177.

SCHEUWIMMER, A. \& S. Nishiwaki. 1982. Comparative studies on three Japanese species of Serpulorbis (Prosobranchia: Vermetidae) with description of new species. Venus 41 (2): 85-101.

SChiaparelli, S. 1995. Contribution to the knowledge of Vermetidae (Mollusca: Gastropoda) from the Ligurian Sea. Bollettino Malacologico 31 (9-12): 267-276.

Schiaparelli, S. \& R. Cattaneo-Vietti. 1999. Functional morphology of vermetid feeding-tubes. Lethaia 32: 41-46.

Schiaparelli, S. \& B. Métivier. 2000. On the identity of "Vermetus" roussaei Vaillant, 1871 (Mollusca, Caenogastropoda, Vermetidae), with the description of a new species. Zoosystema
22: 677-687.

SCUderi, D. 1999. Contributo alla conoscenza dei Vermetidae mediterranei: Vermetus (Thylaeodus) granulatus (Gravenhorst, 1831) e suoi principali morfotipi. Bollettino Malacologico 35 (1-4): 45-48

Simone, L.R.L. 2008. A new species of Fissurella from São Pedro e São Paulo Archipelago, Brazil (Vetigastropoda, Fissurellidae). Veliger 50 (4): 292-304.

Simone, L.R.L. 2009a. A new of Acar (Bivalvia, Arcidae) from São Pedro e São Paulo Archipelago, Brazil. Novapex 10 (1): 9-16.

Simone, L.R.L. 2009b. New Gastropods from the São Pedro e São Paulo Archipelago, Brazil (Vetigastropoda and Caenogastropoda). Strombus 16 (1-2): 11-18.

Soares-Gomes, A.; R.C Villaça \& C. Pezzella. 2001. Reserva biológica do Atol das Rocas: o único Atol no Atlântico Sul e em águas brasileiras. Ciência Hoje 29: 32-39.

Spotorno-Oliveira, P. 2009. Family Vermetidae Rafinesque, 1815, p. 115-119. In: E.C. Rios (Ed.), Compendium of Brazilian Seashells. Rio Grande, Evangraf, 668p.

Spotorno-Oliveira, P.; I. Swoboda \& E.C. Rios. 2003. Estudos preliminares da malacofauna em cubetas de maré do Arquipélago de São Pedro e São Paulo, Brasil. Strombus 09: 01-04.

Spotorno-Oliveira, P.; M.J.M. Silva; J.C.N. Barros; J.A. Francisco; M. Schneider; J.C.L. Batista; P.U. Aquino; G. Vianna \& M.F. Coutinho. 2009. Malacofauna do Arquipélago de São Pedro e São Paulo, Brasil, p. 175-185. In: D.L. Viana, F.H.V. HazıN \& C.T.M.A.C. Souza (Eds). O Arquipélago de São Pedro e São Paulo: 10 anos de Estação Científica. Brasília, SECIRM, 348p.

Spotorno, P.; F.T.S. TÂmega \& C.E. Bemvenuti. 2012. An overview of the recent vermetids (Gastropoda: Vermetidae) from Brazil. Strombus 19 (1): 1-8.

Strathmann, M.F. \& R.R. Strathmann. 2006. A vermetid gastropod with complex intracapusular cannibalism of nurse eggs and sibling larvae and a high potential for invasion. Pacific Science 60: 97-108.

STRONG, E.E. 2003. Refining molluscan characters: morphology, character coding and a phylogeny of the Caenogastropoda. Zoological Journal of the Linnean Society 137: 447-554.

Submitted: 30.XII.2011; Accepted: 26.VIII.2012.

Editorial responsibility: Marcos D.S. Tavares 